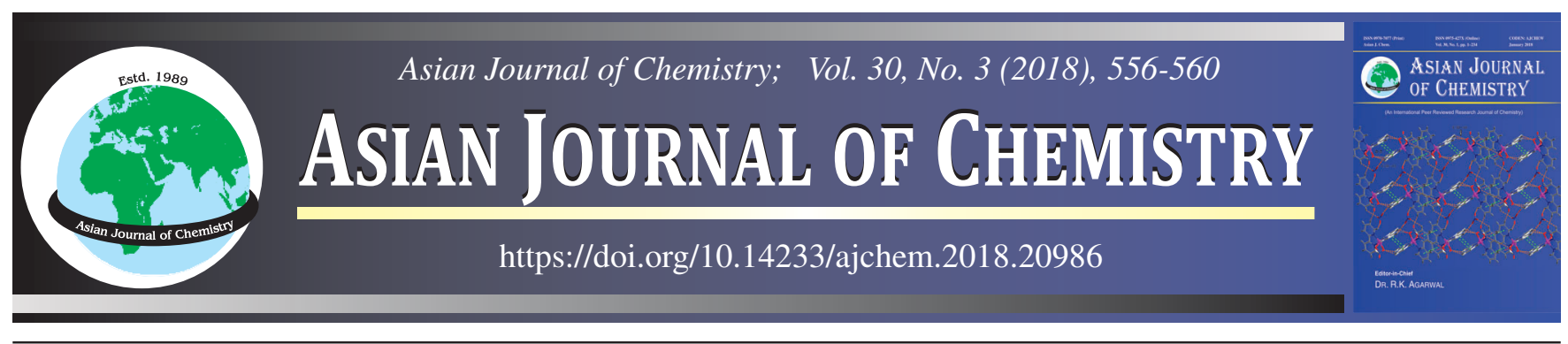

\title{
Synthesis, Characterization and in vitro Antitubercular Evaluation of Some Schiff Bases of Substituted Indoles and their Inclusion Complexes with $\beta$-Cyclodextrin
}

Pramoda Kumar Das ${ }^{1}$, Rabinarayana Sahu $^{1}$, Prakasini Satapathy $^{2}$, Dasarathi Dash $^{2}$ and Bamakanta Garnaik ${ }^{1, *}$

${ }^{1}$ P.G. Department of Chemistry, Berhampur University, Bhanja Bihar-760 007, India

${ }^{2}$ ICMR-Tuberculosis Laboratory, Regional Medical Research Center, Bhubaneswar-751 023, India

*Corresponding author: E-mail: bama_61@ rediffmail.com

Received: 9 August 2017;

Accepted: 31 October 2017;

Published online: 31 January 2018;

AJC-18743

Indole derivatives are best known for their biological importance as bactericides and fungicides which encouraged us to synthesize some Schiff bases of substituted indoles i.e. 2(([1,3,4]thiadiazino[6,5-b]indol-3-ylimino)methyl)substituted phenols. The synthesized compounds are found to exhibit antitubercular activities. With a view to enhance solubility induced potential anti tubercular activities, these synthesized compounds are encapsulated with $\beta$-cyclodextrin. Through elemental and spectral (UV, IR, ${ }^{1} \mathrm{H}$ NMR) characterization, the architecture of the compounds and their inclusion complexes are confirmed. They are also screened for in vitro antitubercular activities by using rifampicin as the reference standard. The synthesized compounds exhibited good antitubercular activity but their inclusion complexes exhibited profound antitubercular activities as compared to their respective compounds.

Keywords: Schiff bases, Inclusion complex, Antitubercular activity, $\beta$-Cyclodextrin.

\section{INTRODUCTION}

Indole nucleus is continuously drawing interest for the development of newer drug moiety due to its wide range of pharmacological activities such as antibacterial [1], antifungal [2], antioxidant [3], antiviral [4], antitubercular [5], anticancer [6], antitumor [7], anti-inflammatory [8], etc. Since this nucleus has shown quite good response as an antitubercular agent, it has become an interest in the field of research. Further, since there are fewer antitubercular drugs available and there are ever increasing fear of drug resistance, it is becoming more and more essential to synthesize some more new drugs with higher potency and low toxicity. So with an objective of exploring the potent antitubercular activities, four different Schiff bases of indole moiety and multiple functional groups are synthesized by condensing salicylaldehyde and 5-substituted salicylaldehydes with a key compound, 2-amino-1,3,4thiadiazino[6,5-b]indole. The key compound is synthesized by methanolic refluxing of indole-2,3, dione with thiosemicarbazide [9]. The structure of the sysnthsized compounds have been analyzed spectroscopically [UV, IR and PMR], which provide a valuable information about their structural features. The synthesized compounds are found to exhibit good antitubercular activities. But the sparingly soluble property of the synthesized compounds in aqueous medium may reduce their bio-accessibility and hence their pharmacological activity.
Therefore to enlist the improvement in their solubility and pharmacological activity, the inclusion complex of the compounds are prepared with $\beta$-cyclodextrin, a useful molecular encapsulant [10] (a host compound). The complex forming tendency of $\beta$-cyclodextrin is mainly due to its special structural design i.e. hydrophilic outer and a hydrophobic interior [11]. The host guest stoichiometry of the complex has been ascertained from the aqueous phase solubility studies of the compound. The change in free energy and stability constant of the inclusion complexes have also been determined, which reveals that the formation of inclusion complex is thermodynamically permissible [12]. The antitubercular activity of this synthesized compounds and their respective inclusion complexes are studied by absolute concentration method and from the findings of the study it is revealed that the inclusion complexes of the compounds exhibit profound antitubercular properties in comparison to their respective compounds.

\section{EXPERIMENTAL}

All the chemicals used in the present investigation are of analytical reagent grade (AR) and procured from Sigma Aldrich. Aqueous solution of the compounds are prepared by using doubly distilled water. All the melting points are determined in open glass capillaries with the help of thermonic melting point apparatus and are uncorrected. Samples are routinely purified by crystallization and checked by TLC. 
Absorption spectra are recorded on Shimadzu-1800 UVvisible spectrophotometer. IR spectra of the compounds and inclusion complexes are recorded as $\mathrm{KBr}$ pellets on a Shimadzu 8400 FTIR spectrophotometer. PMR spectra $\left(\mathrm{CDCl}_{3}\right)$ are measured on NMR spectrometer ( $300 \mathrm{MHz})$ using TMS as an internal standard (chemical shift in $\delta, \mathrm{ppm}$ ).

Synthesis of 2([1,3,4] thiadiazino[6,5b]indol-3ylimino)methyl-4-substituted phenols: The synthesis of the Schiff bases are carried out mainly according to the route in Scheme-I [13].

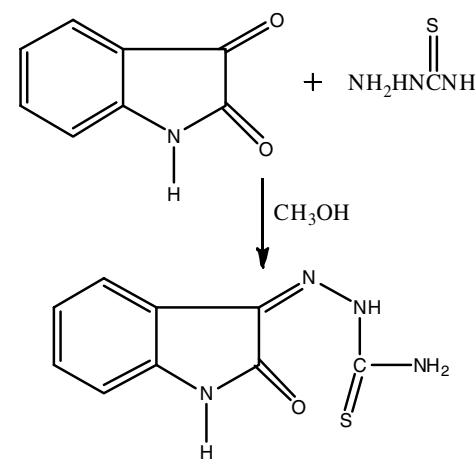<smiles>N/C(S)=N/N=C1/C(O)=Nc2ccccc21</smiles>

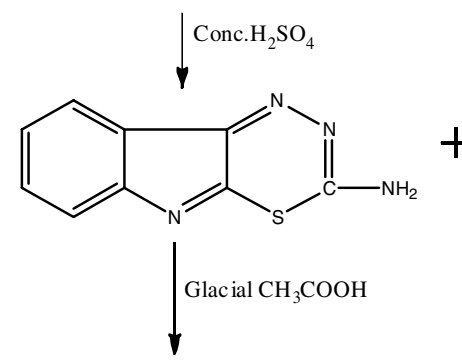

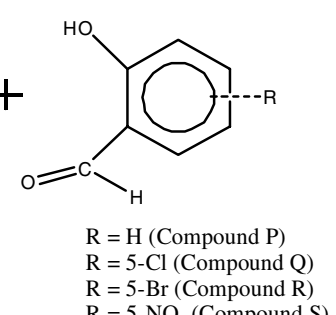

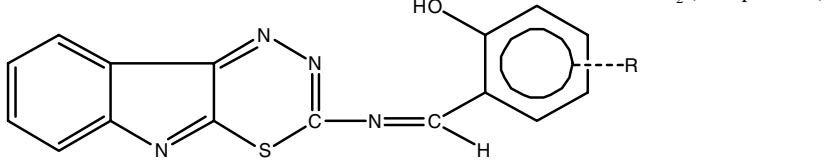

2(([1,3,4]Thiadiazino[6,5-b]indol-3-ylimino)methyl)phenol (P) 2(([1,3,4]Thiadiazino[6,5-b]indol-3-ylimino)methyl)-4-chlorophenol (Q) 2(([1,3,4]Thiadiazino[6,5-b]indol-3-ylimino)methyl)-4-bromophenol (R) 2(([1,3,4]Thiadiazino[6,5-b]indol-3-ylimino)methyl)-4-nitrophenol (S)

\section{Scheme-I}

Step-1: Synthesis of 3-thiosemicarbazido-indol-2-one: A mixture of methanolic solution of indole-2,3-dione (0.0136 $\mathrm{mol})$ and thiosemicarbazide $(0.013 \mathrm{~mol})$ is refluxed for $1 \mathrm{~h}$ in a $500 \mathrm{~mL}$ round bottom flask. The end point of the reaction is checked by thin layer chromatography. Excess of methanol is distilled out and the content is cooled. Yellow precipitate is appeared after the addition of refluxed mixture into ice cold water.

In order to obtain 3-thiosemicarbazido-indol-2-one in pure form, the residue is washed with distilled water, dried and recrystallized by using methanol. The percentage of yield is $80 \%$ and the melting point is $235^{\circ} \mathrm{C}$.
Step-2: Synthesis of 2-amino-1,3,4-thiadiazino[6,5b]indole: About $0.013 \mathrm{~mol}$ of 3-thiosemicarbazido indol-2-one is taken in a beaker. $1 \mathrm{~mL}$ of cold concentrated $\mathrm{H}_{2} \mathrm{SO}_{4}$ is added to it. The mixture is then set aside overnight. The ice-cold water is added to the beaker containing mixture followed by few drops of liquid ammonia till neutralization. The solid mass is found which is filtered, washed with distilled water and dried. The dried residue is recrystallized from ethanol to yield 2-amino1,3,4-thiadiazino[6,5b]indole.

Step-3: Synthesis of 2(([1,3,4]thiadiazino[6,5b]indol3-ylimino)methyl)phenol): To salicylaldehyde (reagent grade, $0.01 \mathrm{~mol}$ ) dissolved in DMF (50 mL), 2-amino-1,3,4-thiadiazino[6,5b]indole $(0.01 \mathrm{~mol})$ is added. The mixture is refluxed for $6 \mathrm{~h}$ in the presence of $0.6 \mathrm{~mL}$ glacial acetic acid. The end point of the reaction is checked by TLC and excess of the solvent is distilled out. It is then poured over crushed ice, which gives a precipitate. The precipitate is filtered through Whatmann 42 filter paper, washed with distilled water and then dried in open air to give a crude product which is then recrystallized form ethanol to give pure compound of 2(([1,3,4]thiadiazino[6,5 b]indol-3-ylimino)methyl)phenol) (compound $-\mathrm{P}$ )

By following the same procedure other 03 compounds $(\mathrm{Q}, \mathrm{R}, \mathrm{S})$ are also synthesized.

Phase solubility measurements: As per Higuchi-Connor method the extent of solubility of the compounds in aqueous medium with different concentrations of $\beta$-cyclodextrin (0-7 mML) is studied [14].

Synthesis of inclusion complexes: Among different methods, co-precipitation method [15] is convenient for the preparation of inclusion complexes of the compounds ( $\mathrm{P}, \mathrm{Q}$, $\mathrm{R}, \mathrm{S}$ ).

Study of thermodynamic properties: From plots of inverse of change in absorbance versus inverse concentration of $\beta$ cyclodextrin the stability constants of the complexes are calculated using Benesi-Hilderband equation [16]:

$$
1 / \Delta \mathrm{A}=1 / \Delta \varepsilon+1 / \mathrm{K}_{\mathrm{T}}[\text { Guest }]_{\mathrm{o}} \Delta \varepsilon \cdot[\beta-\mathrm{CD}]
$$

where $\Delta \mathrm{A}$ is change in absorbance, $\Delta \varepsilon$ is change in absorption coefficient, $\mathrm{K}_{\mathrm{T}}$ is stability constant, [Guest $]_{\mathrm{o}}$ is the concentration of compound and $[\beta-\mathrm{CD}]$ is the molar concentration of $\beta$ cyclodextrin. The values of stability constants for all the complexes are calculated using the relation

$$
\text { Stability constant }\left(\mathrm{K}_{\mathrm{T}}\right)=\text { Intercept/Slope }
$$

The value of $\Delta \mathrm{G}$ at $298 \mathrm{~K}$ is calculated by using the equation:

$$
\Delta \mathrm{G}=-\mathrm{RT} \ln \mathrm{K}_{\mathrm{T}}
$$

where $\mathrm{K}_{\mathrm{T}}$ is the stability constant.

Antitubercular activity: Antitubercular activity was carried out by absolute concentration method [17]. M. tuberculosis H37RV, a laboratory strain culture suspension was prepared and matched with McFarland 1.0 standard. The suspension was diluted 1:100; $0.02 \mathrm{~mL}$ of the dilution was used for inoculation onto LJ (Lowensen-Jensen) medium in the control tube (without drug) as well as tubes containing graded concentration of the compounds and inclusion complexes to be tested. Six concentrations $(1,2,4,10,20$ and $40 \mu \mathrm{g} / \mathrm{mL})$ of each compounds and inclusion complexes were tested and rifampicin 
$(40 \mu \mathrm{g} / \mathrm{mL})$ and isoniazid $(0.2 \mu \mathrm{g} / \mathrm{mL})$ was taken as reference standard. Resistance was expressed in terms of the lowest concentration of the drug that inhibits the growth i.e. MIC. Viability of the organism and inoculums size greatly affects the method.

\section{RESULTS AND DISCUSSION}

All the four compounds (P, Q, R, S) are synthesized in their crystalline solid forms with maximum purity. The maximum inclusion conc. of $\beta$-cyclodextrin has been determined from aqueous phase solubility study (Fig. 1). The inclusion complexes of the synthesized bioactive compounds having indole moiety are prepared with $\beta$-cyclodextrin. The structures of the compounds (P, Q, R, S) and their inclusion complexes have been elucidated from physical properties (Table-2), elemental composition and spectral data such as UV, IR and ${ }^{1} \mathrm{H}$ NMR (Table-3). The composition of elements present in the compounds derived through $\mathrm{CHN}$ analyzer resembles with theoretical data (Table-1).

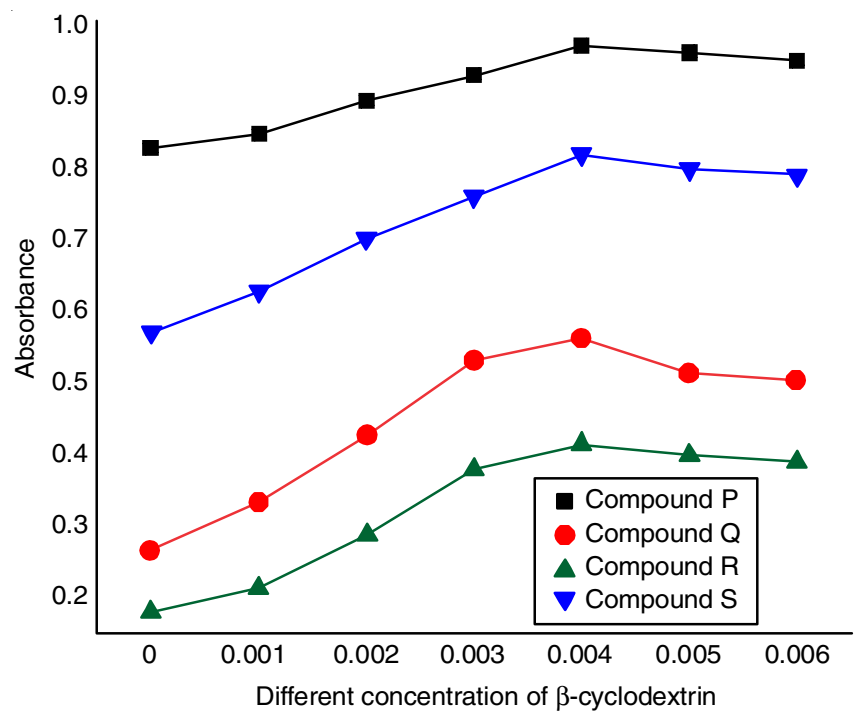

Fig. 1. Plot of absorbance vs. $\beta$-cyclodextrin conc. of the compounds with $\beta$-cyclodextrin
The melting point of inclusion complexes of respective compounds are always marked with increased value which may be assumed through the fact that an additional thermal energy is required for de-encapsulating the compound from the $\beta$-cyclodextrin cavity (Table-2). The IR frequency data 746 (C-Sstr.), 1211(C-N str.), 1338 (C-O str.), 1471, 1541, 1616 (Ar., $\mathrm{C}=\mathrm{C}$ str.), 1714 (C=N str.), 3041(C-H str.) confirms the presence of these groups in the compound. There is a noticeable change in the IR data in all compounds after encapsulation (absorption frequencies shift towards higher energy side), which is featured to the fact that there are some weak interactions within the hydrophobic cage of $\beta$-cyclodextrin (Table3). The host-guest complexation is further supported by NMR data (Table-3). When the NMR data of the compounds are compared with inclusion complexes, signals of different protons reveal that all the protons undergo smaller shifts (towards upfield in case of all the compounds) after encapsulation. These shifts can be explained on the basis of shielding of protons from the applied magnetic field in the cavity of $\beta$-cyclodextrin.

Different graphs are drawn with a definite concentration of the synthesized compounds $v s$. different conc. $(0-10 \mathrm{mM})$ of $\beta$-cyclodextrin. From the graphs it is clear that solubility of the compounds in aqueous medium steadily increase as a function of the concentration of $\beta$-cyclodextrin up to $5^{\text {th }}$ point followed by a smooth decline (Fig. 1). This indicates that the concentration at $5^{\text {th }}$ point is the most appropriate one for getting the higher yield of inclusion complex. Better correlation coefficients are obtained which have values close to unity, which assumes the stoichiometry of these complexes may be 1:1 [18]. By using Benesi-Hilderband relation, thermodynamic stability constants $\left(\mathrm{K}_{\mathrm{T}}\right)$ of host-guest complexes were determined.

Good linear correlations were obtained for a plot of $1 / \Delta \mathrm{A}$ versus $1 /[\beta-\mathrm{CD}]_{\text {o }}$ for compounds as shown compounds in Fig. 2.

The values of $K_{\mathrm{T}}$ for all the complexes were calculated using the relation. $\mathrm{K}_{\mathrm{T}}=$ Intercept/Slope. The $\mathrm{K}_{\mathrm{T}}$ values of the inclusion complexes of compounds with $\beta$-cyclodextrin were found to be $735.71,660.10,860.86,291.25 \mathrm{M}^{-1}$ respectively (Table-4). The data obtained are within a standard range (100

TABLE-1

ELEMENTAL ANALYSIS RESULTS OF THE COMPOUNDS

\begin{tabular}{cccccccc}
\hline \multirow{2}{*}{ Compound } & \multicolumn{7}{c}{ Elemental analysis (\%): Found (calcd.) } \\
\cline { 2 - 7 } & $\mathrm{C}$ & $\mathrm{H}$ & $\mathrm{N}$ & $\mathrm{S}$ & $\mathrm{O}$ & $\mathrm{Cl}$ & $\mathrm{Br}$ \\
\hline $\mathrm{P}$ & $50.00(49.42)$ & $31.25(31.16)$ & $12.50(12.35)$ & $3.12(3.01)$ & $3.12(3.02)$ & - & - \\
$\mathrm{Q}$ & $50.00(49.42)$ & $28.12(31.16)$ & $12.50(12.35)$ & $3.12(3.01)$ & $3.12(3.02)$ & $3.12(3.01)$ & - \\
$\mathrm{R}$ & $50.00(49.42)$ & $28.12(31.16)$ & $12.50(12.35)$ & $3.12(3.01)$ & $3.12(3.02)$ & - & $3.12(3.01)$ \\
$\mathrm{S}$ & $47.05(49.42)$ & $26.47(26.16)$ & $14.70(14.55)$ & $2.94(2.87)$ & $8.82(8.50)$ & - & - \\
\hline
\end{tabular}

TABLE-2

SOME PHYSICAL PROPERTIES OF THE SYNTHESIZED COMPOUNDS AND COMPLEXES

\begin{tabular}{|c|c|c|c|c|c|}
\hline Compound/Complex & m.f. & m.w. & Colour & m.p. $\left({ }^{\circ} \mathrm{C}\right)$ & Yield (\%) \\
\hline Compound-P & $\mathrm{C}_{16} \mathrm{H}_{10} \mathrm{~N}_{4} \mathrm{OS}$ & 306.0 & Light yellow & $232-237$ & 78 \\
\hline I.C.P & & & Pale yellow & $260-265$ & 73 \\
\hline Compound-Q & $\mathrm{C}_{16} \mathrm{H}_{9} \mathrm{~N}_{4} \mathrm{OSCl}$ & 340.5 & Light brown & $87-92$ & 70 \\
\hline I.C.Q & & & Dull white & $255-260$ & 75 \\
\hline Compound-R & $\mathrm{C}_{16} \mathrm{H}_{9} \mathrm{~N}_{4} \mathrm{OSBr}$ & 385.0 & Light brown & $110-115$ & 78 \\
\hline I.C. $\cdot_{\mathrm{R}}$ & & & White & $250-255$ & 73 \\
\hline Compound-S & $\mathrm{C}_{16} \mathrm{H}_{9} \mathrm{~N}_{5} \mathrm{O}_{3} \mathrm{~S}$ & 351.0 & Yellow & $215-220$ & 70 \\
\hline I.C. $\mathrm{s}$ & & & Pale yellow & $270-275$ & 75 \\
\hline
\end{tabular}




\begin{tabular}{|c|c|c|c|}
\hline \multicolumn{4}{|c|}{$\begin{array}{c}\text { TABLE-3 } \\
\text { SPECTRAL DATA OF SYNTHESIZED COMPOUNDS AND COMPLEXES }\end{array}$} \\
\hline $\begin{array}{l}\text { Compound/ } \\
\text { Inclusion }\end{array}$ & $\begin{array}{l}\mathrm{UV} \lambda_{\max } \\
(\mathrm{nm})\end{array}$ & $\operatorname{IR}\left(\mathrm{KBr}, v_{\max }, \mathrm{cm}^{-1}\right)$ & NMR \\
\hline Compound P & 354 & $\begin{array}{l}675 \text { (C-Sstr.), } 1211 \text { (C-N str.), } 1338 \text { (C-O str.), 1474, 1543, } \\
1618 \text { (Ar., C=C str.), } 1691 \text { (C=N str.), } 3041 \text { (C-H str.) }\end{array}$ & $\begin{array}{l}{ }^{1} \mathrm{H} \mathrm{NMR}\left(\mathrm{CDCl}_{3}\right): \delta 6.99-7.9(\mathrm{~d}, 4 \mathrm{H}, \mathrm{Ar}-\mathrm{H}), 7.02-7.60 \\
(\mathrm{~m}, 4 \mathrm{H}, \mathrm{Ar}-\mathrm{H}), 5.32(\mathrm{~s}, 1 \mathrm{H}, \mathrm{OH}), 8.35(\mathrm{~s}, 1 \mathrm{H}, \mathrm{CH})\end{array}$ \\
\hline Inclusion P & 356 & $\begin{array}{l}754 \text { (C-S str.), } 1215 \text { (C-N str.), } 1338 \text { (C-O str.), } 1471 \text {, } \\
\text { 1539, } 1651 \text { (Ar., C=C str.), } 1732 \text { (C=N str.) } 3371 \text { (H- } \\
\text { bonding with } \beta \text {-cyclodextrin) }\end{array}$ & $\begin{array}{l}{ }^{1} \mathrm{H} \mathrm{NMR}\left(\mathrm{CDCl}_{3}\right): \delta 6.25-6.99(\mathrm{~d}, 4 \mathrm{H}, \mathrm{Ar}-\mathrm{H}), 6.6-7.1 \\
(\mathrm{~m}, 4 \mathrm{H}, \mathrm{Ar}-\mathrm{H}), 4.98(\mathrm{~s}, 1 \mathrm{H}, \mathrm{OH}), 7.85(\mathrm{~s}, 1 \mathrm{H}, \mathrm{CH}\end{array}$ \\
\hline Compound Q & 342 & $\begin{array}{l}748 \text { (C-Sstr.), } 1251 \text { (C-N str.), } 1338 \text { (C-O str.), } 1485 \text { (Ar., } \\
\text { C=C str.), } 1714 \text { (C=N str.), } 3120 \text { (C-H str) }\end{array}$ & $\begin{array}{l}{ }^{1} \mathrm{H} \text { NMR }\left(\mathrm{CDCl}_{3}\right): \delta 6.7-7.9(\mathrm{~d}, 5 \mathrm{H}, \mathrm{Ar}-\mathrm{H}), 7.20-7.60 \\
(\mathrm{~m}, 2 \mathrm{H}, \mathrm{Ar}-\mathrm{H}), 5.30(\mathrm{~s}, 1 \mathrm{H}, \mathrm{OH}), 8.40(\mathrm{~s}, 1 \mathrm{H}, \mathrm{CH})\end{array}$ \\
\hline Inclusion Q & 345 & $\begin{array}{l}754 \text { (C-Sstr.), } 1361 \text { (C-N str.), } 1541 \text { (Ar., C=C str.), } 1728 \\
\text { (C=N str.), } 3307 \text { (H-bonding with } \beta \text {-cyclodextrin) }\end{array}$ & $\begin{array}{l}{ }^{1} \mathrm{H} \text { NMR }\left(\mathrm{CDCl}_{3}\right) \delta 6.10-7.10(\mathrm{~d}, 5 \mathrm{H}, \mathrm{Ar}-\mathrm{H}), 6.8-7.2 \\
(\mathrm{~m}, 2 \mathrm{H}, \mathrm{Ar}-\mathrm{H}), 4.75(\mathrm{~s}, 1 \mathrm{H}, \mathrm{OH}), 7.85(\mathrm{~s}, 1 \mathrm{H}, \mathrm{CH})\end{array}$ \\
\hline Compound R & 349 & $\begin{array}{l}746 \text { (C-Sstr.), } 1487 \text { (Ar., C=C str.), } 1714 \text { (C=N str.), } 3041 \\
\text { (C-H str.) }\end{array}$ & $\begin{array}{l}{ }^{1} \mathrm{H} \mathrm{NMR}\left(\mathrm{CDCl}_{3}\right): \delta 6.81-7.70(\mathrm{~d}, 5 \mathrm{H}, \mathrm{Ar}-\mathrm{H}), 7.25-7.55 \\
(\mathrm{~m}, 2 \mathrm{H}, \mathrm{Ar}-\mathrm{H}), 5.28(\mathrm{~s}, 1 \mathrm{H}, \mathrm{OH}), 8.50(\mathrm{~s}, 1 \mathrm{H}, \mathrm{CH})\end{array}$ \\
\hline Inclusion R & 351 & $\begin{array}{l}756 \text { (C-Sstr.), } 1541 \text { (Ar., } \mathrm{C}=\mathrm{C} \text { str.), } 1716 \text { (C=N str.), } 3253 \\
\text { (H-bonding with } \beta \text {-cyclodextrin) }\end{array}$ & $\begin{array}{l}{ }^{1} \mathrm{H} \mathrm{NMR}\left(\mathrm{CDCl}_{3}\right): \delta 6.20-7.10(\mathrm{~d}, 5 \mathrm{H}, \mathrm{Ar}-\mathrm{H}), 6.50-7.10 \\
(\mathrm{~m}, 2 \mathrm{H}, \mathrm{Ar}-\mathrm{H}), 4.65(\mathrm{~s}, 1 \mathrm{H}, \mathrm{OH}), 7.90(\mathrm{~s}, 1 \mathrm{H}, \mathrm{CH})\end{array}$ \\
\hline Compound S & 345 & $\begin{array}{l}740 \text { (C-Sstr.), } 1253 \text { (C-N str.), 1581, } 1622 \text { (Ar., C=C str.), } \\
1699 \text { (C=N str.) }\end{array}$ & $\begin{array}{l}{ }^{1} \mathrm{H} \mathrm{NMR}\left(\mathrm{CDCl}_{3}\right): \delta 7.2-8.5(\mathrm{~d}, 5 \mathrm{H}, \mathrm{Ar}-\mathrm{H}), 7.3-7.70(\mathrm{~m}, \\
2 \mathrm{H}, \mathrm{Ar}-\mathrm{H}), 5.25(\mathrm{~s}, 1 \mathrm{H}, \mathrm{OH}), 8.37(\mathrm{~s}, 1 \mathrm{H}, \mathrm{CH})\end{array}$ \\
\hline Inclusion S & 348 & $\begin{array}{l}754 \text { (C-Sstr.), } 1256 \text { (C-N str.), 1585, } 1631 \text { (Ar., C=C str.), } \\
1725 \text { (C=N str.), } 3244 \text { (H-bonding with } \beta \text {-cyclodextrin) }\end{array}$ & $\begin{array}{l}{ }^{1} \mathrm{H} \text { NMR }\left(\mathrm{CDCl}_{3}\right): \delta 6.5-7.9(\mathrm{~d}, 5 \mathrm{H}, \mathrm{Ar}-\mathrm{H}), 6.8-7.2(\mathrm{~m}, \\
2 \mathrm{H}, \mathrm{Ar}-\mathrm{H}), 4.35(\mathrm{~s}, 1 \mathrm{H}, \mathrm{OH}), 7.70(\mathrm{~s}, 1 \mathrm{H}, \mathrm{CH})\end{array}$ \\
\hline
\end{tabular}

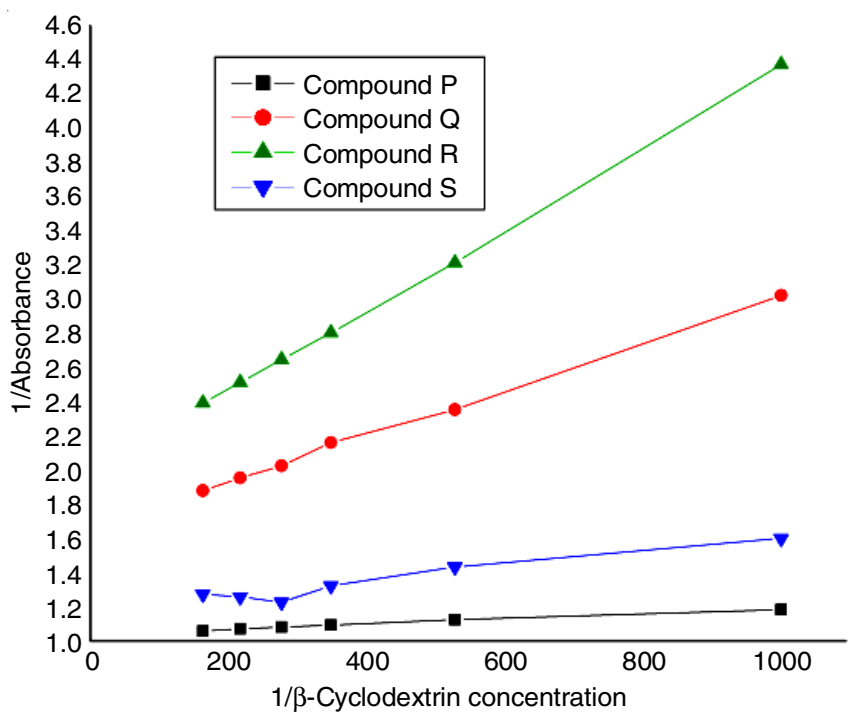

Fig. 2. Plot of $1 /$ absorbance vs. $1 / \beta$-cyclodextrin concentration

to $1000 \mathrm{M}^{-1}$ ). This explains the appreciable stabilities of the inclusion complexes through host-guest interaction like van der Waal's force, hydrophobic interaction etc. [19].

The value of free energy of activation has been calculated and found to be $-16.466,-16.195,-16.858$ and $-14.155 \mathrm{~kJ} / \mathrm{mol}$
(Table-4) for the inclusion complexes of compounds P, Q, R and $S$, respectively. The negative value of free energy change indicates that the inclusion complex formation is a thermodynamically allowed process.

\begin{tabular}{|c|c|c|c|}
\hline \multicolumn{4}{|c|}{$\begin{array}{c}\text { TABLE-4 } \\
\text { THERMODYNAMIC STABILITY CONSTANT AND } \\
\text { FREE ENERGY CHANGE OF INCLUSION COMPLEXES }\end{array}$} \\
\hline $\begin{array}{l}\text { Inclusion } \\
\text { complex of } \\
\text { compound }\end{array}$ & $\begin{array}{c}\text { Equilibrium } \\
\text { constant } \\
\left(\mathrm{K}_{\mathrm{T}}, \mathrm{M}^{-1}\right)\end{array}$ & $\begin{array}{c}\Delta \mathrm{G}=-2.303 \\
\mathrm{RT} \log \mathrm{K} \\
\Delta \mathrm{G}(\mathrm{kJ} / \mathrm{mol})\end{array}$ & $\begin{array}{l}\text { Correlation } \\
\text { coefficient }(r)\end{array}$ \\
\hline I.C.P & 735.71 & -16.466 & 0.9987 \\
\hline I.C. $\cdot{ }_{Q}$ & 660.10 & -16.195 & 0.9756 \\
\hline I.C. $\cdot{ }^{\prime}$ & 860.86 & -16.858 & 0.9899 \\
\hline I.C.s & 291.25 & -14.155 & 0.9887 \\
\hline
\end{tabular}

The data obtained from the antitubercular studies (Table-5) concludes that inclusion complexes of the respective compounds (P, Q, R, S) show good result. The result showed minimum inhibitory concentration for inclusion complexes are lower $(2 \mu \mathrm{g} / \mathrm{mL})$ than the compounds $(4 \mu \mathrm{g} / \mathrm{mL})$. This may be explained on the basis of solubility induced bio-accessibility after encapsulation within host cavity [20].

TABLE-5

ANTITUBERCULAR ACTIVITY OF TEST COMPOUNDS/ INCLUSION COMPLEXES AND STANDARD DRUGS

\begin{tabular}{|c|c|c|c|c|c|c|}
\hline \multirow{2}{*}{$\begin{array}{c}\text { Compound (C)/ } \\
\text { Inclusion complex (IC) }\end{array}$} & \multicolumn{6}{|c|}{ Concentration $(\mu \mathrm{g} / \mathrm{mL})$} \\
\hline & 1 & 2 & 4 & 10 & 20 & 40 \\
\hline C-P & Growth & Growth & No growth & No growth & No growth & No growth \\
\hline IC-P & Growth & No growth & No growth & No growth & No growth & No growth \\
\hline C-Q & Growth & Growth & No growth & No growth & No growth & No growth \\
\hline IC-Q & Growth & No growth & No growth & No growth & No growth & No growth \\
\hline $\mathrm{C}-\mathrm{R}$ & Growth & Growth & No growth & No growth & No growth & No growth \\
\hline IC-R & Growth & No growth & No growth & No growth & No growth & No growth \\
\hline C-S & Growth & Growth & No growth & No growth & No growth & No growth \\
\hline IC-S & Growth & No growth & No growth & No growth & No growth & No growth \\
\hline Rifampicin $(40 \mu \mathrm{g} / \mathrm{mL})$ & \multicolumn{6}{|c|}{ No growth } \\
\hline Isoniazid $(0.2 \mu \mathrm{g} / \mathrm{mL})$ & \multicolumn{6}{|c|}{ No growth } \\
\hline
\end{tabular}




\section{ACKNOWLEDGEMENTS}

The authors greatly acknowledge to The Director, Regional Medical Research Centre (ICMR branch), Bhubaneswar, India for providing the necessary facilities to examine antitubercular activities of the compounds.

\section{REFERENCES}

1. D.S. Mehta, K.H. Sikotra and H.V. Shah, Indian J. Chem., 44B, 2594 (2005).

2. H. Panwar, N. Chaudhary and S. Singh, Rasayan J. Chem., 4, 371 (2011).

3. N.V. Cinchana, P.S. Sujan Ganapathy and S.D. Shruthi, Res. J. Pharm. Biol. Chem. Sci., 2, 353 (2011).

4. M. Tichy, R. Pohl, H.Y. Xu, Y. Chen, F. Yokokawa, P.-Y. Shi and M. Hocek, Bioorg. Med. Chem., 20, 6123 (2012); https://doi.org/10.1016/j.bmc.2012.08.021.

5. S. Lingala, R. Nerella, R. Cherukupally and A.K. Das, Int. J. Pharm. Sci. Rev. Res., 6, 128 (2011).

6. B.C. Hong, Y. Jiang, Y. Chang and S. Lee, J. Chin. Chem. Soc. (Taipei), 53, 647 (2006); https://doi.org/10.1002/jccs.200600086.
7. E. Nassar, J. Am. Sci. Org., 6, 338 (2010).

8. G.P. Kalaskar, M. Girisha, M.G. Purohit, B.S. Thippeswamy and B.M. Patil, Indian J. Heterocycl. Chem., 16, 325 (2007).

9. P.K. Das, R. Sahu and B.K. Garnaik, IOSR J. Appl. Chem., 9, 2265 (2016).

10. B. Yang, J. Lin, Y. Chen and Y. Liu, Bioorg. Med. Chem., 17, 6311 (2009); https://doi.org/10.1016/j.bmc.2009.07.060

11. J. Szetjli, TIBTRCH, 7, 171 (1989).

12. S. Panda and J.K. Tripathy, Asian J. Chem., 23, 1631 (2011).

13. R. Sahu, P.K. Das and B. Garnaik, Pharmachem, 8, 176 (2016).

14. T. Higuchi and K.A. Connor, Adv. Anal. Chem. Instrum., 4, 117 (1965).

15. S.S. Nayak, S. Panda, P. Panda and M.S. Padhy, Bulg. Chem. Commun., 42, 147 (2010).

16. H.A. Benesi and J.H. Hildebrand, J. Am. Chem. Soc., 71, 2703 (1994); https://doi.org/10.1021/ja01176a030.

17. C. Mamatha, M. Thangavel and V. Beaulah, Eur. J. Pharm. Med. Res., 3, 382 (2016).

18. S. Hazra and G.S. Kumar, RSC Advances, 5, 1873 (2015); https://doi.org/10.1039/C4RA10204E.

19. J. Szetli, ed.: W.F. Smolen and L.A. Ball, Controlled Drug Bioavailability, Wiley Interscience, New York, vol. 3, 365 (1985).

20. C. Nicolescu, C. Arama, A. Nedelcu and C.M. Monciu, Farmacia, 58, 78 (2010). 